\title{
Teachers at Work - Developing a Prosocial Personality
}

\author{
Bisera Jevtić and Nedeljko M. Milanović
}

ABSTRACT

\begin{abstract}
Aggressive behavior of students, intolerance, disrespect, disinterest in the needs of others lead to moral catastrophe and the need to pay more attention to the development of prosocial behavior of students and the creation of a better and more humane society. The aim of this research is to gain insight into teachers' attitudes towards the representation, encouragement, and development of prosocial behavior in students. 114 teachers from the territory of the Republic of Serbia participated in the research. A descriptive method was applied, and a survey questionnaire was used as a measuring instrument. Interpreted results show that teachers are familiar with the phrase prosocial behavior and that in working with students they develop and encourage prosociality and morality through conversation, the application of collaborative teaching, acting by personal example and processing topics. Teachers stated that they often organize humanitarian actions, workshops, visits to organizations that provide assistance to exclusive groups of the population and use film materials to encourage and develop the right forms of behavior. The prevalence of immorality and the growing presence of aggressive behavior in children and youth requires that topics on the development of social competencies be more often applied and addressed in the process of upbringing and education, because such actions lead to the development of moral values and prosocial behavior.
\end{abstract}

Keywords: morality, teaching, education, upbringing.

\section{INTRODUCTION}

One of the primary tasks of a modern school is to create a compassionate, empathetic, moral, and positively oriented personality. The pursuit of this task carries with it a great responsibility and commitment of the teacher. The authors Jevtić and Vasić [13] point out that the segment of developing prosocial behavior is still a neglected field of research and study, although the presence of aggressive and negative behavior among students is increasing. Although researches in the field of empathy and prosocial development are limited, it is necessary for teachers to focus on students' moral feelings and prosocial behavior in addition to academic achievements [32]. Therefore, we are witnesses that today school is still focused on emphasizing the acquisition of knowledge and habits, while less attention is paid to the development of prosocial behavior in students.

Topics of aggression and inappropriate behavior among students are increasingly the subject of numerous studies [20], [2], [21], which leads us to the conclusion that it is necessary to focus on developing and encouraging prosocial student behavior, in order to succeed in creating a humane, moral, and valid society. "Increased interest in prosocial behavior appeared as a reaction to the increased aggression of young people and the growing awareness of everyday indifference to the troubles and dangers of others" [15]. Prosocial behavior is extremely important for, "achieving the competence of the individual in various spheres of life: academic, social, family, professional" [31]. Taking into account the above, prosocial behavior does not illustrate onedimensionality and implies sharing with others, helping and comforting others [34]. "Prosocial behavior is a form of moral behavior that aims to help others and which implies a willingness to renounce, a willingness to act in accordance with socially proclaimed norms, humanity, empathy, positive social values, respect for diversity" [23]. Similar to this definition, it is emphasized that, "prosocial behavior is a form of moral conduct that includes socially desirable behaviors such as sharing, helping, and cooperating" [37]. When we talk about prosociality, it is impossible not to define moral values that are understood as "fundamental values of what is right and what is wrong, what is good and what is evil, polite and primitive - that lives in people's hearts and are institutionally shaped" [1].

Therefore, prosocial behavior and moral values are two interdependent and connected categories that intertwine and complement each other and contribute to a valid attitude and positive behavior of an individual towards others. Looking at the above definitions, we can see that prosocial behavior is necessary to develop from an early age, because it is an indispensable component in creating a socially competent personality needed in modern society. Close researches on this topic [36], [16], [30], [7] emphasizes the relevance of the development of moral, empathy, altruism, and humane 
relationships in students. Also, tangential researches [13], [9] that dealt with the role of teachers in developing prosocial behavior of students proclaims the idea that the role of teachers is of special importance in developing and encouraging prosociality and moral dimension in students, and school is a unique place in which true values must be emphasized and nurtured. Starting from this idea that the school is a place that enlightens and where true values are adopted, encouraged, and developed, promotes moral education and socially acceptable and responsible behavior, in this article we will present the relevance of the role of teachers in encouraging and developing students' prosocial behavior and teachers' attitudes toward the application of activities that develop prosocial behavior and moral values. By promoting prosociality and paying attention to this educational dimension in the students' environment, it contributes to young people growing into moral personalities, which has the effect of reducing moral degradation [19].

Today's education strategies impose innovative roles of teachers whose activity should go from teaching to learning, readiness for teamwork and professional development, commitment, and quality in working with different students, ability to reflect and evaluate their own work, to be focused on building tolerance and human relations among students [8]. The role of the modern teacher does not only mean working on the "transfer" of knowledge in the academic aspect, but also engagement aimed at encouraging prosociality and morality in students. Certainly, in addition to the acquisition of knowledge, teachers must take a critical approach to today and include in their work ways and methods that encourage positive behavior in students.

Acting by personal example, applying, and initiating collaborative learning, as well as extracurricular activities are some of the ways that teachers can apply in school practice to promote correct and valid forms of behavior. The benefits of today provide teachers with a variety of ways, methods, and activities that they can methodically apply in the education of a humane and empathic individual.

\section{Social competences of teachers as an indispensable component in the development of prosocial behavior of students}

The success of encouraging moral and prosocial behavior in students also depends on the social competencies of teachers. The term competencies mean "the ability to apply knowledge, to know how and the ability that we recognize in stable/repeated and emerging situations" [5]. Social competencies are a set of knowledge, skills and abilities of an individual that provide him with competent social behavior [17]. A more precise definition is that social competencies imply "possession of personal, interpersonal and intercultural competencies that cover all forms of behavior and enable us to participate in social life, in an efficient and constructive way in increasingly diverse societies" [18]. Social intelligence, knowledge, social skills, as well as personality traits are listed as the leading factors on which social competencies depend [24].

Determining what competencies an individual needs for the 21 st century, the author Suzić includes the following in social competencies: understanding other people, interpreting group relationships, collaboration, making connections, being a leader and being led, teamwork skills, communication and interaction, helping and supporting others, sensitivity to the developmental needs of others, tolerance, democracy, a sense of belonging [33]. Mlinarević and Tomas [26] state that social competence implies empathy, altruism, cooperation and mutual help, the right attitude towards oneself and others, the expression of a sense of value, uniqueness, and a positive image of oneself.

"Teachers who will conduct modern teaching, ie teaching focused on students, should work on their own professional development in order to more successfully prepare their students for the world of adults" [40]. Therefore, in order for teachers to successfully prepare students for the world of adults, they must pay attention to the segment of social competencies, because they are the basis on which socially correct and valid treatment and behavior towards others is built.

A socially competent teacher is a teacher who gives students the opportunity to interpret group relationships, to freely express their opinions and attitudes without the presence of fear and resistance, applies models in which students are in the roles of leader and guided, while they share roles and learn and develop collaborative and team skills [9]. Therefore, a socially competent individual is portrayed by the manifestation of interpersonal skills, socially responsible behavior, social independence, behavior control, intercultural cooperation, as well as assertive social skills [14].

Taking all the above into account, we notice that a socially competent teacher strives and pays attention to activities and content related to prosociality and moral values, which leads to the final outcome - the development of social competencies in students. Only a socially competent teacher can encourage and develop social competencies in students [12]. We conclude that a socially competent teacher is one who encourages cooperation through group work in teaching, initiates critical thinking, proclaims true value orientations, respects students' opinions, develops empathy and altruism, pays attention to constructive conflict resolution, positively directs by personal example and strives to develop prosociality and moral values by discussion and conversation with students, preparing students for socially desirable, valid and correct behavior and behavior.

\section{METHODOLOGY}

\section{A. Sample}

The population consists of teachers from the territory of the Republic of Serbia. The study involved 114 teachers, 59.6\% $(\mathrm{f}=68)$ females and $40.4 \%(\mathrm{f}=46)$ males. Of the total number of employees, $32.5 \%(\mathrm{f}=37)$ have a university degree and $67.5 \%(f=77)$ have a master's. According to the environment in which they work, $71.1 \%(\mathrm{f}=81)$ of teachers work in urban schools, while $28.9 \%(\mathrm{f}=33)$ of teachers work in a rural school.

\section{B. Method}

A descriptive research method was applied in the research. In addition to the application of frequencies and estimates, a chi-square was used in this study to determine statistical significance, while the consent of the respondents on a five- 
point scale of Likert-type assessment was calculated using the scale value index (ISV). Of the instruments, a survey questionnaire was applied. Guided by the tangent research mentioned in the theoretical part of the article, a special questionnaire for the needs of this empirical research was purposefully constructed.

\section{Research Procedure}

During January 2021, an online version of the survey was conducted, using the Google questionnaire. We decided to conduct the research online due to the pandemic caused by the Covid 19 virus. At the beginning of the questionnaire, the information was pointed out that the completion of the questionnaire was anonymous, that it was for the needs of scientific research and instructions were given on how to fill in the questionnaire. The obtained data were statistically processed in the statistical program Statistical Program for Social Scientists 21 (SPSS 21).

\section{OBJeCTIVES OF THE STUDY}

The subject of this research is the role of teachers in encouraging and developing prosocial behavior of students. The aim of the research is to gain insight into teachers' attitudes towards the representation, encouragement, and development of prosocial behavior in students.

In accordance with the defined goal, the following research tasks are created:

1. Are teachers familiar with the phrase prosocial behavior and how would they describe a student who exhibits this form of behavior?

2. Investigate whether there is a statistically significant difference in terms of whether teachers have acquired skills and knowledge during education about the importance and ways of developing prosocial behavior in students with regard to education.

3. To investigate whether there is a statistically significant difference in terms of whether teachers' pay attention to the prosocial form of behavior in students with regard to gender.

4. What form of work, in the opinion of the teacher, is the most suitable for encouraging prosocial behavior?

5. Whether and in what way teachers improve individually on ways and methods of developing prosocial and moral behavior in students?

6. Analyze how often teachers in working with students apply certain activities to encourage prosocial behavior and moral values in students.

7. What are the views and suggestions of teachers on improving the ways of encouraging prosocial behavior and moral values in students?

Based on a clearly formulated subject, goal, and tasks of the research, we can assume that teachers encourage, develop and promote prosocial values in students and that their attitude towards prosociality is positive.

\section{RESUlTS AND DISCUSSION}

Aggressive behavior of students, intolerance, disrespect, disinterest in the needs of others, lead to moral catastrophe and the need to do something about the positive orientation of students and creating a better and more humane society.

As the subject of this research is aimed at questioning teachers about the development of prosociality, the introductory question was to examine whether teachers are familiar with the phrase prosocial behavior and how to describe a student who exhibits this form of behavior?

The distribution of teacher responses indicates that $81.6 \%$ $(\mathrm{f}=93)$ of teachers stated that they were familiar with the phrase prosocial behavior, $18.4 \% \quad(\mathrm{f}=21)$ of teachers responded with partial, while there are no teachers who answered no. Looking at the above answers of the respondents, we notice that most teachers are familiar with the term prosocial behavior.

In order for the teachers to support their answer in the previous question, which concerned the familiarity with the term prosociality, the question followed how the teachers would describe in one word the student who exhibits prosocial behavior. Teachers were given the freedom to answer by asking the question openly.

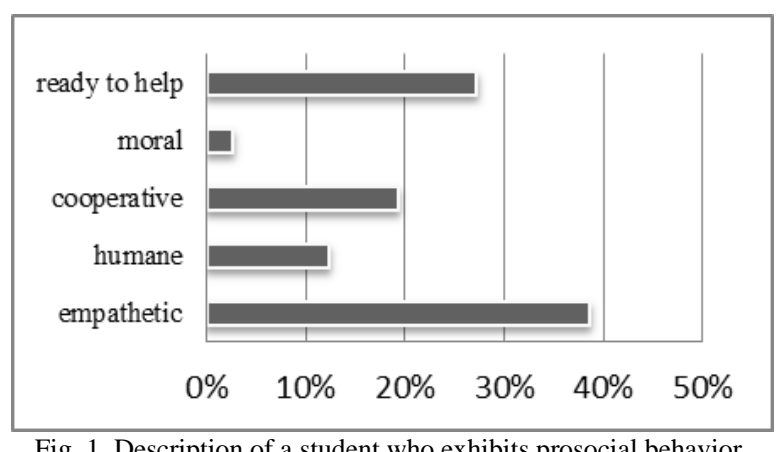

The sorted answers in Graph 1 show that $27.2 \%$ ( $\mathrm{f}=31$ ) of teachers described a student who exhibits prosocial behavior as a student who is willing to help, $2.6 \%(\mathrm{f}=3)$ of teachers answered that it is a student with moral values, $19.3 \%(\mathrm{f}=22)$ cooperative, $12.3 \% \quad(\mathrm{f}=14)$ humane, while $38.6 \% \quad(\mathrm{f}=44)$ teachers stated that he was an empathetic student. Therefore, we notice that all surveyed teachers, both those who answered in the previous question that they were familiar with the term prosocial behavior and those who answered in part, described well the student who exhibits prosocial behavior. In many societies, socially competent students are described as responsible, dedicated, friendly, willing to provide help and support, and have well-developed emotion control skills [6].

With the next research task, we wanted to investigate whether there is a statistically significant difference in the question of whether teachers acquired skills and knowledge during education about the importance and ways of developing prosocial behavior in students, given the professional qualifications of teachers.

The difference in the frequency of responses was statistically significant $(\chi 2=36.137 ; \mathrm{df}=1 ; \mathrm{p}=0.00)$ between teachers who have a university degree and teachers who are masters who said yes, $80.7 \%(\mathrm{f}=92)$ and $19.3 \%(\mathrm{f}=22)$ of teachers answered that they partially acquired skills and knowledge about the importance and ways of developing prosocial behavior in students. Therefore, the analyzed answers show a statistically significant difference, where teachers with the title of master more often stated that they acquired knowledge and skills than teachers with higher 
education. It is essential that higher education institutions that educate teachers include in their programs and proclaim contents that include the prosocial and moral dimension.

After asking about the acquired knowledge and skills related to prosocial behavior, we wanted to investigate whether there is a statistically significant difference in whether teachers' pay attention to the prosocial form of behavior in students, with regard to gender.

The difference in the frequency of responses was statistically significant $(\chi 2=15,953 ; \mathrm{df}=1 ; \mathrm{p}=0.00)$ between female and male teachers who said yes, $76.3 \%(\mathrm{f}=87)$ and $23.7 \%(\mathrm{f}=27)$ teachers responded that they pay partial attention to the prosocial form of behavior in students. More often, female teachers stated that during the implementation of classes, they pay attention to topics related to prosociality, than male teachers. Teachers may have their own affinities, sympathies or antipathies towards certain contents or teaching units, but in the educational process they must not neglect any pedagogical segment that purposefully affirms, encourages, and enlightens students. Therefore, the gender structure in this case should not be reflected in the treatment of certain topics in school that present positive behavior.

If the teachers answered yes or partially to the previous question, it was necessary to state the ways in which they encourage and develop prosocial behavior in students.

The largest number of surveyed teachers, more precisely $39.5 \%(\mathrm{f}=45)$ answered that they develop prosocial behavior by talking to students, $24.6 \% \quad(\mathrm{f}=28)$ pay attention in collaborative teaching, $13.2 \%(\mathrm{f}=15)$ of teachers pointed out the importance of acting by personal example, while $22.8 \%$ $(\mathrm{f}=26)$ pointed out that they deal with topics that have prosocial and moral characteristics. The fewest respondents cited acting by personal example, and this segment is one of the most important ways to develop prosocial behavior in students. The teacher is next to the family, the most important actor in the process of upbringing and education. By his personal example, he should have a valid and positive effect on students and be a correct model by which students can be imitated. Prosociality cannot be developed only in a theoretical way, but it is necessary that it be accompanied by activities of teachers that encourage moral values and positive behavior of students. If the teacher tells the students about tolerance and respect for other people, in addition to theoretical presentation, he should apply the principles of tolerance and respect for other people in his daily life. By acting in this way, the teacher is a unique pedagogical example to the students. There are many opportunities that teachers can use in teaching and extracurricular activities in order to encourage positive student behavior. The imagination and creativity of teachers, as well as everyday life situations can serve and be the topic of discussions in which it is said what is right and what is not, what to do, how to act, how to resolve conflicts, how to help and provide support, how to treat yourself and others correctly. The author Opić [28] lists the following activities that can lead to the development of prosocial behavior, and they are: helping among students of the same grade; assisting in the work and organization of the school; helping at the family and local community level.

The next task was to examine from which subjects teachers most often talk about topics of prosocial behavior.

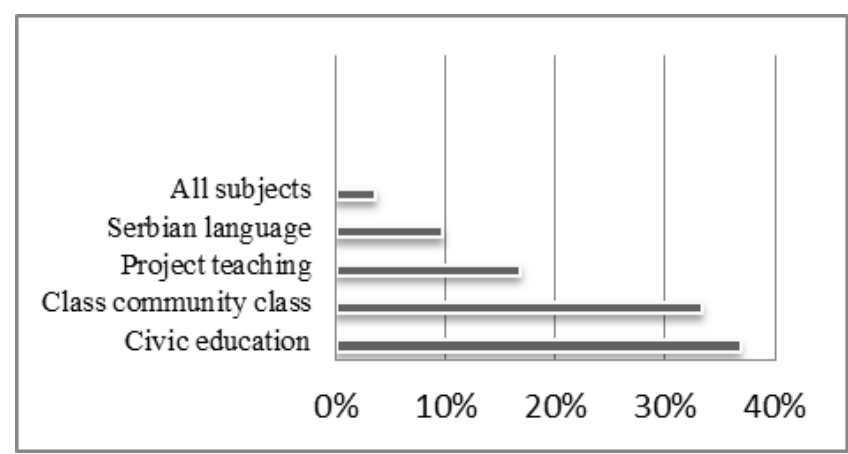

Fig. 2. List of subjects from which teachers deal with topics about prosociality.

The goal of the subject Civic Education is to develop, encourage and strengthen social competencies in students and commitment to topics that promote proper and prosocial behavior. Therefore, the largest number of teachers, more precisely $36.8 \%(\mathrm{f}=42)$ stated that they deal with the topics of prosocial behavior from Civic Education, 33.3\% ( $\mathrm{f}=38)$ state the Class Community Class, 16.7\% ( $\mathrm{f}=19)$ states Project teaching, $9.6 \%$ ( $\mathrm{f}=11$ ) of teachers pointed out the Serbian language, while only $3.5 \%(\mathrm{f}=4)$ of teachers answered that they deal with topics about prosociality in all subjects. Therefore, the subjects Civic Education and Class Community Class are the most common subjects in which teachers speak more actively and process topics and contents related to positive social behavior. A small number of teachers stated that they pay attention to prosociality in the Serbian language subject. Literary works, characters, actions, conflicts, and dilemmas can be of educational importance and help teachers to promote correct actions and moral values through the interpretation of the characteristics of characters, situations, conflicts. "The greatest value of literature is not so much in the examples that students can imitate and answer that it gives, but in the problems that it opens for thinking" [25]. The least surveyed teachers answered that they talk about prosociality in all subjects. Teaching is also an educational activity, and it is necessary to emphasize valid patterns of behavior that students should adopt and accept.

Teachers were asked to name the topic they had last discussed with the students, and to relate to prosocial behavior. The mentioned question was of an open type.

Teachers are actively addressing topics related to prosociality. The most present topics that teachers dealt with students are topics related to cooperation, relationships with others, tolerance, humanity. The results of the research [9] show that more than half of the surveyed teachers in their classes often talk about cooperation and tolerance in order to encourage prosocial behavior. Numerous manuals and practicums of civic education contain workshops and activities on the topics of prosociality, which are described in detail and provide an opportunity for teachers to discuss them often with students. It is not enough to just talk about these topics, but it is also necessary to apply them in practice, because only in this way students become more familiar with abstract concepts such as empathy, altruism, cooperation, tolerance and others.

Then we wanted to find out which form of work, in the opinion of the teacher, is the most suitable for encouraging prosocial behavior and to state the reasons.

$30.7 \%(\mathrm{f}=35)$ of teachers cite pair work as the most 
appropriate form of work to encourage prosociality, $57.9 \%$ $(\mathrm{f}=66)$ of teachers cite group work, $11.4 \% \quad(\mathrm{f}=13)$ cite workshop work. Thus, teachers unanimously cited collaborative forms in the work that contribute to the development of positive social behavior in students. As reasons, teachers stated that through joint work, students practically develop positive patterns of behavior: cooperation, tolerance, active listening, respect for others and expressing and arguing their own views. An interactive environment can significantly serve in the promotion and development of positive behavior in students [39]. The application of a group form of work "leads to better interpersonal relationships among students, develops the ability to take on the role of another, reduces the number of conflicts and encourages prosocial behavior. In order to achieve a common goal, students in collaborative groups help each other and encourage each other" [13]. In order to be successful in encouraging prosociality and moral values of students, the teacher should apply different forms, methods and ways of working with students. Group work is an ideal way in which through the processing of teaching materials, the teacher encourages interaction and cooperation among students. "Quality indicators, grouped around interpersonal relationships, are mostly related to cooperative learning in teaching that encourages affirmation, communication and cooperation or mutual readiness to help" [27]. There are numerous topics about prosociality that can be realized through group discussions and debates. The teacher can present one story/situation and divide the students into groups, where each group would work together to debate the possibilities, take certain positions, and find solutions that would, in the end, present to others. Such a discussion should have the following requirements: students should feel free to express their opinions and views on a particular topic; key actors in the discussion should be students who comment on each other and challenge suggestions and possibilities; the teacher should encourage interaction, moral reasoning and require students to concretely present their solutions, supporting them with arguments [25]. As prosociality and morality are two interdependent components, by applying this way of working, the teacher encourages both moral reasoning and prosocial behavior. By participating in the group, students have the opportunity to develop prosocial behavior, because they cooperate and help each other [34]. If the teacher "encourages cooperation and assistance in the classroom, solidarity, tolerant attitude towards different opinions, encourages students to ask questions and express their opinions, favorable conditions are created for achieving cognitive, social and emotional outcomes of educational work" [31].

As training is one of the indispensable obligations of teachers, the next question was whether teachers are individually trained on the ways and methods of developing prosocial and moral behavior in students. The distribution of answers about individual teacher training is as follows: $95.6 \%$ $(f=109)$ of teachers answered yes, $4.4 \%(f=5)$ of teachers stated that they do it occasionally, while there were no negative answers. Almost all of the surveyed teachers stated that they pay attention to individual development regarding the ways and methods of developing prosociality and moral values in students.
If the teachers answered the previous question with yes or occasionally, it was necessary to state the ways in which they acquire knowledge and skills about the ways and methods of developing prosocial and moral behavior in students.

Teachers pay attention to individual development in terms of encouraging positive behavior in students. There are no large percentage differences and deviations in the answers of the surveyed teachers. There are no large percentage differences and deviations in the answers of the surveyed teachers. The use of contemporary literature was stated by the largest number of teachers, more precisely $36 \%(f=41)$. Then, active participation in activities and projects was stated by $34.2 \%$ ( $f=39$ ) of teachers. Through personal engagement and active participation in activities and projects that promote valid and correct forms of behavior, teachers have the opportunity to acquire practical knowledge and skills, which can be important to them in school practice. $29.8 \%(\mathrm{f}=34)$ of teachers as a form of individual training stated the monitoring of programs related to the development of social skills in students.

The next research task was for teachers to indicate on a five-point Likert-type assessment scale how often they organize activities that encourage, develop, and promote prosocial behavior and moral values.

The highest index of scale value was calculated when claiming that teachers organize workshops in which they deal with the topics of prosocial behavior and moral values (ISV=4.90). Workshops intended for the development of social skills, encourage understanding of one's own needs, self-awareness and self-affirmation, the aim of these workshops is to raise awareness of some general communication phenomena and laws (verbal, nonverbal messages, rumors, stereotypes and prejudices) and to influence understanding of situations and adoption strategy for solving them" [11]. Therefore, the workshop way of working can serve for the affirmation and development of social competencies in students. Also, a high value was calculated for the claim that teachers watch films with students that carry messages about prosocial behavior and moral values (ISV= 4.89). The results of the research [13] show that teachers, in addition to conversations, also use film materials to show examples of prosocial behavior and encourage students to adopt true values.

A high value (ISV=4.75) has also calculated at the claim that teachers organize humanitarian actions. Participation of students in the preparation and implementation of humanitarian actions implies their good will and encouragement of striving for the right values and right actions. This activity is known as volunteering, and it is defined as a lifestyle that is closely related to the values that the individual prefers and implies an unpaid activity that contributes to social well-being [22]. Volunteer work "is associated with desirable social values to which the individual shows inclinations and is marked by prosocial behavior" [41]. Volunteering is one of the practical activities that should be applied and encouraged in school, because it nurtures the desire for help, compassion, and altruism. As volunteering is most often a function of leisure time, extracurricular activities for teachers are another way that can be helpful in developing students' prosocial orientation. Participation in extracurricular activities affects the 
socialization of students, through nurturing positive personality traits, humanity, solidarity, and interactivity [3]. Through school sections, gatherings, socializing, the true values that students should strive for, accept, and adopt in their behavior are promoted and nurtured. Through teaching and extracurricular activities, the teacher has the opportunity to achieve positive communication and develop prosocial forms [4]. Therefore, in addition to teaching, the benefits of extracurricular activities should be used to encourage morality, prosociality and overall positive development of students.

A slightly lower scale index was calculated for the claim that teachers visit NGOs and other institutions that provide assistance to vulnerable groups (ISV=3.92).

The mean value was calculated for the claim that teachers organize debates whose topics concern prosocial behavior and moral reasoning (ISV=3.21). "The debate program in schools and universities aims at recreational and entertaining activity of pupils and students because the debate is based on joint work, it is competitive, and serious research of topics distances from school monotony and mnemonic adoption of materials. Adoption of debate skills enables general easier research and analysis of the issues we deal with, analytical way of thinking..." [38]. Debates are a conversation in which the interlocutors take certain positions in the presence of listeners, whose meaning is to reach a solution to the presented dilemma, and the outcome depends on the logic, wit and activity of the participants [35]. Debating is a very interesting activity that offers unsteady and unusual approaches and demands to students. In addition to developing critical thinking and shrewdness, debating also promotes finding the right solutions, ideas, and adequate, prosocial, and moral conduct.

The last research task was to examine how, in the opinion of teachers, ways to encourage prosocial behavior and moral values in students can be improved and enhanced.

TABLE I: THE ARRANGEMENT OF CHANNELS

TABLE I. TEACHERS' SUGGESTIONS ON HOW WAYS TO ENCOURAGE PROSOCIALITY AND MORALITY CAN BE IMPROVED

\begin{tabular}{ccc}
\hline \hline $\begin{array}{c}\text { Teachers' suggestions on how ways to } \\
\text { encourage prosocial behavior and moral } \\
\text { values can be improved }\end{array}$ & $\mathrm{f}$ & $\%$ \\
\hline $\begin{array}{c}\text { Greater support from the school } \\
\text { administration for the implementation of } \\
\text { prosocial activities }\end{array}$ & 33 & 28,9 \\
$\begin{array}{c}\text { Development of a program on developing } \\
\text { students' social skills }\end{array}$ & 15 & 13,2 \\
$\begin{array}{c}\text { Inclusion of more diverse activities and } \\
\text { forms of work in teaching related to } \\
\text { prosocial behavior and moral values } \\
\text { Educational programs and seminars }\end{array}$ & 19 & 16,7 \\
$\begin{array}{c}\text { Strengthening cooperation with the local } \\
\text { community }\end{array}$ & 5 & 36,8 \\
\hline \hline
\end{tabular}

Therefore, the above suggestions of teachers are realistic and achievable and can be taken into account and applied in school practice.

\section{CONCLUSIONS}

This article presents the role of teachers in the development of prosocial behavior, as well as the importance of social competencies of teachers as an indispensable component in the development and encouragement of prosociality and moral dimension. In addition to the theoretical review, the attitudes of teachers on encouraging, promoting, and applying activities and content that contribute to the development of prosocial behavior in students were analyzed.

The results of the research show that teachers are familiar with the phrase prosocial behavior. Teachers with a master's degree more often stated that they had acquired knowledge and skills to encourage prosociality in students. Also, female teachers were more likely to pay attention to prosocial behavior than male teachers, who were more likely to respond occasionally.

The analyzed results of this research show that teachers state that the most common ways of developing prosocial behavior and moral values are talking to students, applying collaborative teaching, acting by personal example, and processing topics related to prosociality and morality. Teachers unanimously pointed out that collaborative teaching (pair work, group work, workshop work) is the most suitable for promoting and developing positive behavior among students. The calculated scale value index indicates a high agreement of teachers on the organization and implementation of activities that raise awareness of prosocial and moral behavior, while the claim about the application of debates in teaching is the calculated mean value.

The analysis of empirical data leads us to the conclusion, where the general hypothesis of the research is confirmed that teachers encourage, develop, and promote prosocial values in students and that their attitude towards prosociality is positive. In addition to the instrument that covered, most often, closed questions, the lack of this research may be a smaller sample of respondents, as well as the method of data collection that took place online, via Google questionnaires. The key results of this research are that teachers pay attention to prosocial behavior and moral values and strive to develop social competencies in students. The prevalence of immoral behavior and the growing presence of aggressive behavior among children and young people requires that topics on the development of social competencies be primary in the upbringing and education of modern society.

The researched problem is very topical, considering the deviance of society, false values and the moral collapse that increasingly reflects the present. The contribution of this article can serve as an idea and starting point for future research and authors to promote, develop and encourage correct, moral, valid and prosocial behavior in children and youth, because in creating a humane and empathetic society must start with the youngest, and adults must be an adequate example and role model to follow.

\section{REFERENCES}

[1] Baker, W. America's Crisis of Values: Reality and Perception. Princeton: Princeton University Press, 2005.

[2] Bilić, V. Povezanosti medijskog nasilja s agresivnim ponašanjem prema vršnjacima. Odgojne znanosti, 12 (2 (20)), 263-281. 2010.

[3] Budimir-Ninković, G., \& Popov, S. Pedagogija. Jagodina: Fakultet pedagoških nauka, Univerziteta u Kragujevcu, 2016.

[4] Bulić, A. Činioci prosocijalnog i agresivnog ponašanja učenika osnovnih škola. Nastava i vaspitanje, 67(3), 525-540. 2018. https://scindeks-clanci.ceon.rs/data/pdf/0547-3330/2018/054733301803525B.pdf.

[5] Chisholm, L. Bridges for Recognition Cheat Sheet: Proceedings of the SALTO Bridges for Recognition: Promoting Recognition of Youth 
Work across Europe, Leuven-Louvain. Universität Innsbruck, D: Institut für Erziehungswissenschaften, 2005.

[6] Denham, S.A., Bassett, H. H., \& Wyatt, T. The socialization of emotional competence. In J. Grusec \& P. Hastings (Eds.), Handbook of socialization: Theory and research, 2008. (pp. 614-637). New York: Guilford.

[7] Dimitrijević, D. Radioničarski rad u nastavi u kontekstu podsticanja empatije. Godišnjak za pedagogiju, 2020. 5(1), 93-104.

[8] Đermanov, J., Kostović, S., \& Đukić, M. Obrazovanje u različitosti i za različitost: dimenzije profesionalnog razvoja nastavnika. U M. Oljača (ur.), Modeli stručnog usavršavanja nastavnika za interkulturalno vaspitanje i obrazovanje, 2006. (51-68). Novi Sad: Filozofski fakultet.

[9] Đorđević, M. Uloga nastavnika u podsticanju prosocijalnog ponašanja učenika. Zbornik radova Pedagoškog fakulteta, Užice, 2019. (21), $27-$ 44.

[10] Ivanović, O. Mogućnosti podsticanja prosocijalnog ponašanja kod dece osnovnoškolskog uzrasta pomoću posebnih programa vaspitnog rada. Religija i tolerancija, 2010. 8(14), 289-304.

[11] Janković, S., \& Kovač-Cerović, T. Osnovne pretpostavke radioničarskog postupka. U Kovač-Cerović, T., Rosandić, R., Popadić, D. (prir.), Učionica dobre volje: školski program za konstruktivno rešavanje sukoba. Beograd: Grupa Most, 1995.

[12] Jevtić, B. Socijalna kompetentnost nastavnika. Zbornik 16, Vršac: Visoka škola strukovnih studija za vaspitače „Mihailo Palov“, 2011.

[13] Jevtić, B., \& Vasić, A. Nastavnik - fasilitator prosocijalnosti. Sinteze - časopis za pedagoške nauke, književnost i kulturu, 2014. 3(6), 75-86.

[14] Jevtić, B. Retro(per)spektiva (a)socijalizacije. Niš: Filozofski fakultet, 2015.

[15] Jevtić, B., \& Ilić, S. Podsticanje prosocijalnog ponašanja učenika u srednjim školama. Godišnjak za pedagogiju, 2018. 29-45

[16] Jukić, R. Moralne vrijednosti kao osnova odgoja. Nova prisutnost, 2013. XI (3), 401-416.

[17] Kanning, U. P., 2009. Diagnostik sozialer Kompetenzen (2. Aufl.). Göttingen: Hogrefe Verlag. Kopf, M., Leipold, J., \& Seidl, T., 2010. Kompetenzen in Lehrveranstaltungen und Prüfungen Handreichung für Lehrende. Mainzer Beiträge zur Hochschulentwicklung, Band 16. Mainz: Zentrum für Qualitätssicherung und -entwicklung.

[18] Kompirović, T. P. Sociodemografske determinante kao prediktor socijalnih kompetencija učenika osnovne škole na Kosovu i Metohiji. Zbornik radova Filozofskog fakultet u Prištini, 50(4), 271-291. 2020.

[19] Kuswendi, U. Teacher strategy in development prosocial behavior of students in elementary school. PrimaryEdu-Journal of Primary Education, 2019. 3(1), 6-16.

[20] Mancini, J. A., \& Huebner, A. J. Adolescent Risk Behavior Patterns: Effects of Structured Time-Use, Interpersonal Connections, SelfSystem Characteristics, and Socio-Demographic Influences. Child and Adolescent Social Work Journal, 2004. 647-668

[21] Marušić, I., \& Pavin-Ivanec, T. Praćenje vršnjačkog nasilja u osnovnim školama: spolne razlike u učestalosti i vrstama nasilnog ponašanja.
Ljetopis socijalnog rada, 2008. 15 (1), 5-19.

[22] Miliša, Z. Odnos mladih prema volontiranju, radu i slobodnom vremenu. Diacovensia, 2008. 16(1-2), 93-115.

[23] Milovanović, R. Socijalne kompetencije kandidata za pedagoški fakultet. Nastava i vaspitanje, 2012. 61(4), 662-679.

[24] Milovanović, R. Interakcija i komunikacija u vaspitnom radu. Jagodina: Fakultet pedagoških nauka, 2010.

[25] Miočinović, Lj. Moralni razvoj i moralno vaspitanje. Beograd: Institut za pedagoška istraživanja, 2004

[26] Mlinarević, V., \& Tomas, S. Partnerstvo roditelja i odgajitelja čimbenik razvoja socijalne kompetencije djeteta. Magistra Iadertina. 2010. 5, 5; 143-158.

[27] Omerović, M., \& Zukorlić, M. Obučavanje budućih nastavnika radi podsticanja razvoja socijalne kompetencije učenika. DHS, 2018. 307 322.

[28] Opić, S. Mogući program razvoja socijalne kompetencije učenika u primarnom obrazovanju. Pedagogijska istraživanja, 2010. 7 (2), 219228.

https://hrcak.srce.hr/index.php?show=clanak\&id_clanak_jezik=17448 7

[29] Požar, H. F. The competence of teachers in modern education. Sintezečasopis za pedagoške nauke, književnost i kulturu, 2016. 5(10), 23-34.

[30] Rupčić, D., Steiner Jelić, S., \& Kelam I. Uloga skrbnog mišljenja empatije u obrazovanju. Arhe, 2019. 26(31), 229-262.

[31] Spasenović, V. Prosocijalno ponašanje i školsko postignuće učenika Zbornik Instituta za pedagoška istraživanja, 2004. 131-150.

[32] Spinrad, T. L., \& Eisenberg, N. Empathy, prosocial behavior, and positive development in the schools. In R. Gilman, E. S. Huebner, \& M. J. Furlong (Eds.), Handbook of positive psychology in schools (pp. 119-129). New York: Routledge/Taylor \& Francis Group, 2009.

[33] Suzić, N. Pedagogija za XXI vijek. Banja Luka: TT-centar, 2005.

[34] Ševkušić, S. Efekti kooperativnog učenja na prosocijalno ponašanje učenika. Zbornik Instituta za pedagoška istraživanja, 1994. 26, 149 165.

[35] Škarić, I. Temeljci suvremenog govorništva. Zagreb: Školska knjiga., 2000

[36] Špelić, A., Zuliani, Đ., \& Milošević, I. Prosocijalnost i empatija u kontekstu integracijskih razreda. Hrvatska revija za rehabilitacijska istraživanja, 2013. 49 (1), 135-150.

[37] Vasta, R., Haith, M. M., \& Miller, S. A. Dječja psihologija. Jastrebarsko, Naklada Slap, 1998

[38] Vlaisavljević, S. Debata u otvorenom društvu. Sarajevo: Centar za kulturu dijaloga, 2011

[39] Villardón-Gallego, L., García-Carrión, R., Yáñez-Marquina, L., \& Estévez, A. Impact of the interactive learning environments in children's prosocial behavior. Sustainability, 2018, 10(7), 21-38.

[40] Zrilić, S., \& Marin, K. Kompetencije u suvremenoj školi - potrebe prakse iz perspektive učitelja. Školski vjesnik, 2019. 68 (2), 389-400.

[41] Zrno, J. Uključivanje volontera u nastavu. Život i škola, 2013. LIX (29), 385-396. 